\title{
PENGEMBANGAN LKPD BERBASIS PREDICT-OBSERVE-EXPLAIN UNTUK MELATIHKAN BERPIKIR KRITIS PESERTA DIDIK PADA MATERI DAYA HANTAR LISTRIK LARUTAN
}

\section{T. Olivia ${ }^{*}$, Muchlis $^{2}$}

1,2 Prodi Kimia, Universitas Negeri Surabaya, Surabaya, Indonesia

*Corresponding Author: muchlis@unesa.ac.id

\section{ART ICLE INFO}

Article history:

Received February 26, 2021

Revised March 03, 2021

Accepted June 26, 2021

Available online July 25, 2021

Kata Kunci:

Lembar Kerja Peserta Didik, Predict-Observe-

Explain, Berpikir Kritis

Keywords:

Student Worksheet,

Predict-Observe-Explain,

Critical Thinking

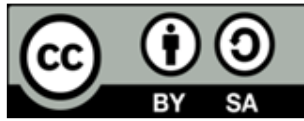

This is an open access article under the CC BY-SA license.

Copyright (C) 2021 by Author. Published by Universitas Pendidikan Ganesha.

\begin{abstract}
A B S T R A K
Kimia merupakan salah satu mata pelajaran yang dianggap sulit oleh peserta didik.Adanya pandangan negative mengenai pembelajaran kimia serta kurangnya penggunaan media oleh guru berdampak pada rendahnya kemampuan berpikir kritis siswa pada mata pelajaran kimia. Adapun tujuan dari penelitian ini yakni untuk mengembangkan Lembar Kerja Peserta Didik(LKPD) berbasis Predict-Observe-Explain (POE) untuk melatihkan keterampilan berpikir kritis pada materi Daya Hantar Listrik Larutan. Penelitian ini merupakan jenis penelitian pengembangan yang dilakukan dengan model 4D (define, design, develop, dissiminate). Subjek yang terlibat dalam penelitian ini yakni 12 orang siswa SMA.Pengumpulan data dalam penelitian dilakan dengan dilakukan dengan menggunakan metode validasi, observasi, tes, serta angket. Sedangkan instrumen yang dipakai antara lain lembar telaah, validasi, aktivitas peserta didik, tes tertulis (pretest dan posttest), keterlaksanaan model pembelajaran serta angket respon peserta didik. Data dari hasil penelitian kemudian dianalisis secara deskriptif kualitatif, dimana hasil penilaian dan masukan dari para dosen digunakan untuk perbaikan LKPD yang telah dikembangkan. Hasil analisis menunjukkan bahwa pada komponen isi LKPD berbasis POE memperoleh hasil validitas sebesar $89,44 \%$ dengan kategori sangat valid, komponen penyajian memperoleh hasil $86 \%$ dengan kategori sangat valid, komponen kebahasaan memperoleh hasil $82,5 \%$ dengan kategori sangat valid, serta komponen kegrafikan memperoleh hasil $82,5 \%$ dengan kategori sangat valid. Berdasarkan hasil tersebut dapat disimpulkan bahwa LKPD berbasis model POE sangat valid untuk dikembangkan dan dibelajar kepada peserta didik, kususnya untuk meningkatkan kemampuan berpikir kritis pada mata pelajaran kimia.
\end{abstract}

\section{A B S T R A C T}

Chemistry is one of the subjects that are considered difficult by students. The existence of a negative view of chemistry learning and the lack of media use by teachers have an impact on the low critical thinking skills of students in chemistry subjects. The purpose of this research is to develop a Student Worksheet based on Predict-Observe-Explain to practice critical thinking skills in the Electrical Conductivity of Solutions. This research is a type of development research conducted with a $4 D$ model. The subjects involved in this study were 12 high school students. Data collection in the study was carried out by using the methods of validation, observation, tests, and questionnaires. While the instruments used include study sheets, validation, student activities, written tests (pretest and posttest), implementation of learning models and student response questionnaires. The data from the research results were then analyzed descriptively qualitatively, where the results of the assessment and input from the lecturers were used to improve the LKPD that had been developed. The results of the analysis show that the POE-based LKPD content component obtained a validity result of $89.44 \%$ with a very valid category, the presentation component obtained $86 \%$ results in a very valid category, the linguistic component obtained $82.5 \%$ results in a very valid category, and the graphic component obtained the results of $82.5 \%$ with a very valid category. Based on these results, it can be concluded that the POE model-based worksheets are very valid to be developed and studied by students, especially to improve critical thinking skills in chemistry subjects. 


\section{PENDAHULUAN}

Pendidikan abad 21 merupakan model pendidikan yang berupaya untuk mendorong peserta didik agar menguasai berbagai keterampilan dengan tujuan membentuk peserta didik menjadi pribadi yang sukses dalam hidup dan lebih responsif terhadap perubahan dan perkembangan jaman (Maemunah, 2020; Makhrus et al., 2018; Syamsuar \& Reflianto, 2018). Keterampilan yang dikembangkan pada pendidikan abad 21 terdiri dari keterampilan berpikir kritis, keterampilan memecahkan masalah, kolaborasi, dan keterampilan berkomunikasi (Redhana, 2019; Sugiyarti et al., 2018). Pelaksanaan pendidikan abad 21 di Indonesia didukung dengan adanya kurikulum 2013 edisi revisi 2017 yang dalam pelaksanaannya juga menuntut peserta didik untuk bersikap aktif, kritis, inovatif serta kreatif (Anggraini et al., 2017). Keterampilan berpikir kritis yang dikembangkan dalam kegiatan belajar merupakan suatu tahapan berpikir peserta didik saat melakukan analisis pada masalah yang dihadapi dengan tersusun serta terinci, mengelompokkan masalah tersebut dengan cermat serta teliti, dan melakukan identifikasi serta menelaah informasi untuk merencanakan taktik penyelesaian masalah (Azizah et al., 2018; Farib et al., 2019). Kemampuan berpikir kritis penting untuk dibiasakan kepada peserta didik sebab dengan adanya kemampuan berpikir kritis seseorang akan mampu berpikir secara mendalam dan menyeluruh mengenai masalah yang berada dalam jangkauan pengalamannya. Terdapat 5 komponen yang terkandung dalam proses berpikir kritis diantaranya adalah memberikan penjelasan sederhana (elementary clarification), membangun keterampilan dasar (basic support), menyimpulkan (inference), memberikan penjelasan lebih lanjut (advanced clarification), menyusun strategi serta taktik (strategy and tactics) (Novita, 2018; Rachman et al., 2017). Kemampuan berpikir kritis dapat digunakan untuk memutuskan serta mengatasi masalah yang kompleks, dimana hal ini diperlukan di dalam pembelajaran kimia (Astuti et al., 2018). Kimia merupakan kelompok ilmu yang mempelajari mengenai struktur dan komposisi zat (Ismawati, 2017; Nuraini et al., 2018). Didalam mata pelajaran kimia tidak hanya memuat sistem hafalan, namun juga perhitungan, serta belajar konsep yang perlu dipahami, dimana ketiganya harus saling berkaitan untuk membangun pemahaman dari peserta didik dalam mempelajari kimia (Chairani \& Muchlis, 2019). Karakteristik ilmu kimia perlu diperhatikan dengan tujuan peserta didik akan lebih mengkaji pengetahuan dan mendapatkan pemahaman yang bermakna dengan melakukan eksperimen serta dapat mengaplikasikan dalam kehidupan sehari - hari. Salah satu materi yang dibelajarkan pada ilmu kimia yakni materi daya hantar listrik larutan yang memiliki keterkaitan dengan kehidupan seharihari, dan berhubungan dengan pengertian menyeluruh dari aspek sub makroskopik, mikroskopik, dan simbolik (Islamiyah et al., 2019).

Hanya saja pada kenyataannya materi daya hantar listrik larutan dianggap materi yang cukup sulit dipahami, hal ini disebabkan karena kurangnya kemampuan berpikir kritis siswa, sehingga tidak mampu mengkaji materi dengan baik (Susilowati et al., 2018). Rata-rata kemampuan peserta didik dalam mengerjakan soal materi daya hantar listrik larutan disetiap indikator berpikir kritis hanya sebesar $14 \%$ (Nurazizah et al., 2017). Hal ini didukung oleh hasil observasi yang dilakukan di SMAN 1 Kota Mojokerto. Hasil observasi menunjukkan bahwa sebanyak $80 \%$ peserta didik menganggap pelajaran kimia tidak mudah dipahami, 70\% peserta didik menganggap materi daya hantar listrik larutan cukup sulit dipahami, $75 \%$ menyatakan jarang menggunakan LKPD yang menerapkan fenomena dalam kehidupan sehari - hari, dan sebanyak 65\% peserta didik menyatakan LKPD yang digunakan tidak melatihkan keterampilan dalam memecahkan masalah.Kurangnya tanggapan positif siswa mengenai materi kimia disebabkan karena kurangnya kemampuan guru untuk menyediakan media serta perangkat pembelajaran yang memadai. Pelaksanaan pembelajaran hanya dilaksanakan dengan metode konvensional tanpa penggunaan media, sehingga proses pembelajaran terkesan menoton. Jika dibiarkan secara terus menerus akan berdampak pada rendahnya tingkat pemahaman materi serta rendahnya hasil belajar kimia siswa. Sehingga untuk mengatasi hal tersebut dibutuhkan suatu inovasi dalam kegiatan pembelajaran yang mampu merangsang kemampuan berpikir siswa.

Salah satu upaya yang dapat dilakukan untuk mengatasi masalahnya rendahnya kemampuan berpikir kritis siswa pada materidaya hantar listrik larutan yakni dengan mengembangkan media LKPD (lembar kerja peserta didik).LKPD merupakan kumpulan dari lembaran yang berisi materi berdasarkan kompetensi dasar (KD), ringkasan, dan kegiatan yang dilakukan peserta didik (Pranowo et al., 2021; Rizalini \& Sofyan, 2018; Satura et al., 2021). LKPD yang dikembangkan dapat dikatakan ideal apabila sudah sama dengan model pembelajaran yang dipakai, sehingga LKPD akan dapat berhasil, efektif, memuaskan, dan bermakna bagi siswa (Hamidah et al., 2018; Muthoharoh et al., 2017).Pengembangan LKPD akan lebih maksimal apabila dilakukan dengan berbasis model Predict, Observe, Explain(POE).Model pembelajaran POEberguna untuk menumbuhkan pemahaman awal yang dimiliki peserta didik, dengan diberikannya kesempatan pada peserta didik dalam potensi berpikir, mengkondisikan peserta didik untuk berdiskusi, menyemangati peserta didik untuk penggalian konsep serta membangkitkan peserta didik untuk menjalankan penyelidikan (Putri et al., 2018). 
Pembelajaran menggunakan model POE mengupayakan untuk memaksimalkan peran peserta didik dalam mengajukan pertanyaan, menyampaikan pendapatnya, menyimpulkan serta mengkomunikasikan hasil analisisnya baik di dalam kelompok maupun di dalam kelas (Basir et al., 2018). Model POE terdiri dari 3 tahapan pelaksanaan yang terdiri dari tahap Predict (prediksi), yang dimana pada tahap ini peserta didik memprediksi suatu fenomena atau permasalahan.Tahapan kedua yakni tahap Observe, dimana pada tahap ini peserta didik dapat melakukan pengamatan atau mengamati video percobaan untuk membantu dalam pembuktian dugaan. Tahapan ketiga yakni tahap Explain, dimana pada tahap ini peserta didik membandingkan hasil pengamatannya dengan prediksi sebelumnya,setela itu menjelaskan dengan didasarkan dari pengetahuannya sendiri (Muna, 2017; Suhaesa et al., 2019; Sumartini, 2017). Tahapan-tahapan yang terkandung dalam model POE memungkinkan peserta didik untuk belajar secara sistematis dan memaksimalkan proses berpikirnya. Beberapa penelitian yang telah dilakukan sebelumnya menyebutkan bahwa model pembelajaran POE mampu meningkatkan kemampuan berpikir kritis peserta didik (Alfiyanti et al., 2020). Penelitian lainnya juga menyebutkan bahwa strategi POE dapat digunakan saat melakukan pelatihan keterampilan berpikir kritis hal ini dapat dilihat melalui perolehan persentase nilai gains score sebesar 6\% kategori rendah, 26\% kategori sedang dan 68\% kategori tinggi(Amaliyah \& Harun, 2019). Penelitian selanjutnya menyebutkan bahwa media LKPD berbasis PBL valid dikembangkan dan dibelajarkan dalam pembelajaran kimia, karena dapat bersifat praktis, efektif, dan mampu meningkatkan kemampuan berpikir kritis siswa (Astuti et al., 2018). Berdasarkan beberapa penelitian tersebut dapat dikatakan bahwa media LKPD merupakan media yang valid untuk dikembangkan. Hanya saja pada penelitian sebelumnya belum terdapat penelitian yang mengembangkan media LKPD berbasis model POE sehingga pada penelitian ini difokuskan untuk mengembangkan media LKPD berbasis mode POE dengan tujuan untuk melatihkan keterampilan berpikir kritis pada materi Daya Hantar Listrik Larutan yg layak untuk digunakan.

\section{METODE}

Penelitian ini merupakan jenis penelitian pengembangan (research and development) yang dikembangkan dengan menggunakan model pengembangan 4D. Model pengembangan 4D terdiri atas 4 tahapan pengembangan yang terdiri dari tahap define (pendefinisian), design (perancangan), develop (pengembangan), dan disseminate (penyebaran) (Ain \& Mitarlis, 2020). Hanya saja pada penelitian ini tidak menggunakan tahap disseminate sehingga penelitian hanya melalui tiga tahap antara lain define, design, serta develop dengan proses uji coba terbatas. Tujuan dari penelitian ini agar dihasilkannya inovasi produk berwujud LKPD (Lembar Kerja Peserta Didik) untuk materi Daya Hantar Listrik untuk melatihkan keterampilan berpikir kritis. Subjek yang terlibat dalam penelitian ini yakni 12 siswa kelas X MIPA 2 SMAN 1 Kota Mojokerto. Kegaiatan pembelajaran dilakukan secara daring (online) dengan 2 kali pertemuan, sehingga dalam 2 kali pertemuan tersebut akan dikembangkankemampuanberpikir kritis pada peserta didik dengan diterapkannya model pembelajaran POE.Pengumpulan data dalam penelitian dilakukan dengan menggunakan metode validasi, observasi, tes, serta angket.Perangkat pembelajaran yang dipakai yakni berupa Silabus, RPP, serta LKPD yang telah dikembangkan. Sedangkan instrumen yang dipakai antara lain lembar telaah, validasi, aktivitas peserta didik,tes tertulis (pretest dan posttest), keterlaksanaan model pembelajaran serta angket respon peserta didik. Layak atau tidaknya LKPD dapat dilihat melalui validitas, kepraktisan serta keefektifan. Data dari hasil penelitian kemudian dianalisis secara deskriptif kualitatif, dimana hasil penilaian dan masukan dari para dosen digunakan untuk perbaikan LKPD yang telah dikembangkan.Lembar validasi diberikan kepada 3 dosen kimia dan 1 guru kimia sebagai validator, yang dianalisis secara deskriptif kuantitatif.Penilaian terhadap LKPD kemudian dikonveriskan kedalam skala Likert dengan kategori penilaian seperti pada Tabel 1. Selanjutnya untuk menentukan validitas dilakukan berdasarkan kriteria interpretasi skor seperti pada tabel 2.

Tabel 1. Skala Likert

\begin{tabular}{cc}
\hline Nilai skala & Kriteria \\
\hline 1 & Sangat Kurang \\
2 & Kurang \\
3 & Cukup \\
4 & Baik \\
5 & Sangat baik \\
\hline
\end{tabular}


Tabel 2.Kriteria Interpretasi

\begin{tabular}{cc}
\hline Persentase (\%) & Kriteria \\
\hline $0-20$ & Tidak Valid \\
$21-40$ & Kurang Valid \\
$41-60$ & Cukup Valid \\
$61-80$ & Valid \\
$81-100$ & Sangat Valid \\
\hline
\end{tabular}

LKPD dinyatakan valid jika persentase yang diperoleh sebesar $\geq 61 \%$ yaitu pada kategori valid atau sangat valid.Aktivitas belajar peserta didik dilakukan dengan menggunakan media LKPD berbasis model POE. Pengamatan mengenai aktifitas pembelajaran dilakukan oleh 2 orang observer dengan menggunakan instrument lembar observasi.Aktivitas peserta didik dikatakan mendukung kelayakan dari LKPD jika diperoleh persentase sebesar $\geq 61 \%$ dengan kategori baik atau baik sekali. Lembar tes diberikan agar diketahui keterlatihan keterampilan berpikir kritis peserta didik serta agar diketahui tuntas atau tidaknya hasil belajar untuk pendukung keefektifan dari LKPD. Nilai yang diperoleh kemudian dianalisis menggunakan perhitungan $\mathrm{N}$-Gain score. Hasil perhitungan kemudian dikonversikan kedalam tabel kriteria $N$-Gain score, seperti yang pada Tabel 3.

Tabel 3. Kriteria Tingkat N-Gain Score

\begin{tabular}{cc}
\hline Skor & Kriteria \\
\hline $\mathrm{g} \geq 0,7$ & Tinggi \\
$0,3 \leq \mathrm{g}<0,7$ & Sedang \\
$\mathrm{g} \leq 0,3$ & Rendah \\
\hline
\end{tabular}

LKPD dapat dinyatakan sukses untuk melatih keterampilan berpikir kritis peserta didik dan dikatakan efektif jika skor $N$-Gain $\geq 0,3$ yaitu pada kriteria sedang atau tinggi.Ketuntasan klasikal ditentukanmenggunakan perhitungan ketuntasan individu diatas KKM. Keefektifan LKPD juga didukung dari keterlaksanaan model pembelajaran, yang bertujuan untuk mengamati kualitas keterlaksaan pada kesesuaian proses pembelajaran dengan sintaks POE. Pengamatan keterlaksaan sintaks dikerjakan 2 observer dengan memakai instrumen lembar observasi, lalu diperoleh keterlaksaan model pembelajaran yang relevan dengan indikator pengamatan. Skor penilaian keterlaksanaan sintaks model pembelajaran POE terdapat di Tabel 4. Pentuan kategori dilakukan dengan menggunakan tabel kriteria kualitas keterlaksanaan model pembelajaran yang disajikan pada Tabel 5. Keterlaksanaan model pembelajaran dapat dikatakan baik jika memperoleh nilai kualitas keterlaksanaan $\geq 61 \%$ yaitu kategori baik atau sangat baik.

Tabel 4. Skor Penilaian Keterlaksanaan Model Pembelajaran

\begin{tabular}{cc}
\hline Skor & Keterangan \\
\hline 0 & Pembelajaran tidak terlaksana \\
1 & Terlaksana kriteria buruk \\
2 & Terlaksana kriteria cukup \\
3 & Terlaksana kriteria baik \\
4 & Terlaksana kriteria sangat baik \\
\hline
\end{tabular}

Tabel 5.Kriteria Kualitas Keterlaksanaan Model Pembelajaran

\begin{tabular}{cc}
\hline Persentase (\%) & Kriteria \\
\hline $0-20$ & Buruk \\
$21-40$ & Kurang \\
$41-60$ & Cukup \\
$61-80$ & Baik \\
$81-100$ & Baik Sekali \\
\hline
\end{tabular}

(Riduwan, 2015) 


\section{HASIL DAN PEMBAHASAN}

Hasil

Media LKPD berbasis model POE dikembangkan dengan menggunakan model 4D yang terdiri dari tahap define (pendefinisian), design (perancangan), develop (pengembangan) dan disseminate (penyebaran). Hanya saja tahap disseminate (penyebaran) tidak dapat dilaksanakan karena adanya pandemic covid-19. Pada tahap pertama yakni tahap Define dilakukan pengumpulan data awal dengan melaksanakan studi pendahuluan.Pada tahap ini juga dilakukan analisis kebutuhan, kompetensi, peserta didik, serta konsep.Analisis dijalankan dengan cara mewawancarai guru kimia serta melaui angket prapenelitian. Pra penelitian dilaksanakan di SMAN 1 Mojokerto. Setelah tahap define selesai dilakukan perancangan media dilanjutkan pada tahap Design yaitu penyusunan rencana awal, instrumen, serta pemilihan media. Pada tahap design dihasilkan rancangan awal LKPD. Terdapat 1 LKPD yang dirancang dengan memuat 2 sub bab dari materi daya hantar listrik larutan. Tahapan pada LKPD menyesuaikan tahapan POE. Dalam LKPD berbasis POE, terdapat 2 sub bab yaitu sub bab Elektrolit dan Non Elektrolit, serta sub bab Elektrolit Lemah dan Elektrolit kuat. LKPD yang dikembangkan disesuaikan dengan pembelajaran daring, dimana pada tahap observe, peserta didik melakukan pengamatan dangan mengamati video percobaan yang tersedia di youtube serta menggunakan laboratorium maya yang diakses melalui website.Rancangan LKPD dapat dilihat pada Gambar 1 dan 2.

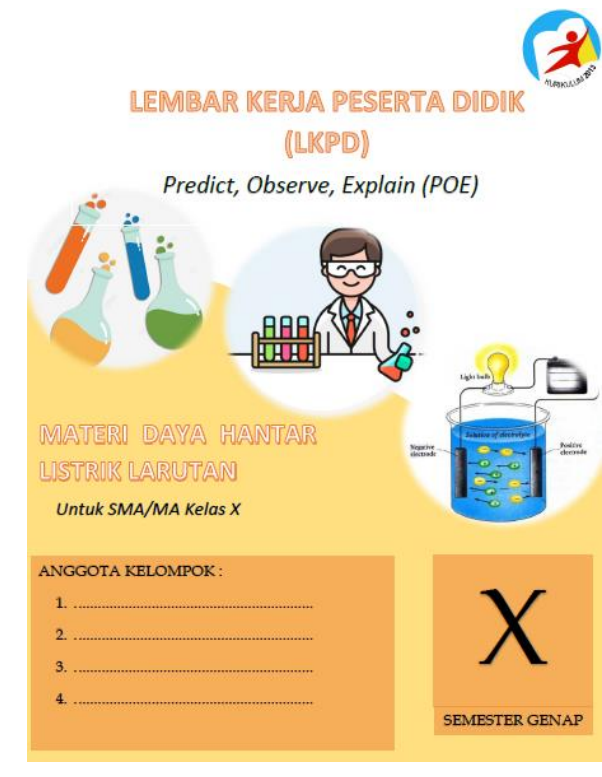

Gambar 1. Cover LKPD Berbasis POE

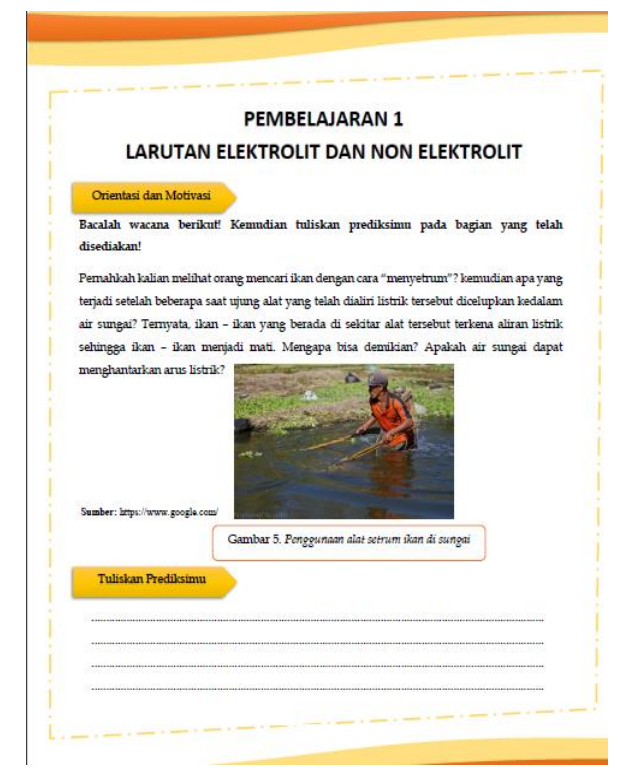

Gambar 2. ContohTahapan POE dalam LKPD

Setelah LKPD selesai dirancang, pengembangan media dilanjutkan pada tahap develop, dimana pada tahap ini dilakukan proses telaah serta validasi seperangkat bahan ajar oleh para dosen, serta 1orang guru. Validasi dilakukan oleh 3 dosen kimia Unesa serta 1 guru kimia SMAN 1 Mojokerto. Proses yang dilakukan yaitu validasi lalu diikuti dengan revisi, dan dihasilkan perangkat pembelajaran yang telah diperbaiki berdasarkan saran dari penelaah dan validator. LKPD yang telah divalidasi dan dinyatakan valid maka akan diujicobakan kepada peserta didik. Hasil uji validitas LKPD dapat dilihat pada Tabel 6.

Tabel 6. Hasil Validitas LKPD yang dikembangkan

\begin{tabular}{ccc}
\hline Komponen yang divalidasi & Persentase (\%) & Kriteria \\
\hline Isi & 89,44 & Sangat Valid \\
Penyajian & 86 & Sangat Valid \\
Bahasa & 82,5 & Sangat Valid \\
Kegrafikan & 82,5 & Sangat Valid \\
\hline
\end{tabular}

Berdasarkan hasil pengujian validitas dapat diketahui bahwa konten atau isi yang disajikan dalam LKPD sangat sesuai dengan kebutuhan peserta didik sehingga memperoleh hasil persentase sebesar $89,44 \%$ dengan kategori sangat valid. Selanjutnya komponen penyajian memperoleh persentase sebesar $86 \%$ dengan kategori sangat valid, komponen bahasa memperoleh persentase $82,5 \%$ dengan kategori 
sangat valid, serta komponen kegrafikan memperoleh persentase 82,5\% dengan kategori sangat valid. Selain pengujian validitas LKPD penelitian juga dilakukan dengan menguji aktivitas belajar peserta didik selama dibelajarkan menggunakan LKPD berbasis model POE. Adapun hasil observasi aktifitas belajar peserta didik dengan menggunakan media LKPD berbasis model POE dapat dilihat pada Tabel 7.

Tabel 7. Hasil observasi aktivitas peserta didik

\begin{tabular}{ccccc}
\hline \multirow{2}{*}{ Pertemuan } & \multicolumn{3}{c}{ Aspek yang diamati (\%) } & \multirow{2}{*}{ Rata - Rata } \\
\cline { 2 - 4 } & Predict & Observe & Explain & \\
\hline P1 & 87,5 & 91,67 & 91,67 & 90,28 \\
P2 & 91,67 & 95,83 & 91,67 & 93,06 \\
\hline
\end{tabular}

Berdasarkan Tabel 7 dapat diketahui bahwa keterlaksanaan pembelajaran sangat baik dengan menggunakan LKPD berbasis POE yang dikembangkan, hal ini didukung dengan kegiatan peserta didik saat aktivitas belajar mengajar memakai LKPD tersebut. Aktivitas peserta didik rata - rata meningkat dari pertemuan 1 ke pertemuan 2. Pada tabel 8 dapat dilihat bahwa fase predict pada penelitian ini lebih rendah dibandingkan dengan fase yang lainnya, hal ini dikarenakan peserta didik masih kesulitan dalam membuat prediksi. Peserta didik juga cukup kesulitan untuk mengaitkan hasil observasi dengan prediksi. Namun secara kesulurahan peserta didik mengikuti aktivitas pembelajaran dengan cukup aktif serta telah sesuai fase - fase dari POE. Ketika pembelajaran beberapa peserta didik bertanya apabila kurang paham terhadap materi pelajaran. Keaktifan dalam menjawab serta antusias dalam mengikuti pembelajaran juga tergolong cukup aktif. Selain mampu meningkatkan aktifitas belajar peserta didik media LKPD juga mampu meningkatkan kemampuan berpikir kritis siswa, hal ini dapat dilihat pada hasil analisis kemampuan berpikir kritis yang disajikan pada Tabel 8.

Tabel 8. Hasil Analisis N-Gain Score Peserta Didik

\begin{tabular}{cccccc}
\hline No. & Nama Peserta Didik & Pretest & Posttest & N-Gain & Kategori \\
\hline 1. & ABPHS & 45 & 85 & 0,72 & Tinggi \\
2. & CNSI & 75 & 95 & 0,8 & Tinggi \\
3. & FSN & 30 & 75 & 0,64 & Sedang \\
4. & HAM & 45 & 90 & 0,81 & Tinggi \\
5. & IPR & 40 & 85 & 0,75 & Tinggi \\
6. & MKA & 65 & 90 & 0,71 & Tinggi \\
7. & MHRGZ & 25 & 80 & 0,73 & Tinggi \\
8. & NDW & 35 & 75 & 0,61 & Sedang \\
9. & NNS & 60 & 90 & 0,75 & Tinggi \\
10. & RAR & 40 & 75 & 0,58 & Sedang \\
11. & SM & 30 & 80 & 0,71 & Tinggi \\
12. & TYNP & 40 & 80 & 0,67 & Sedang \\
\hline \multicolumn{4}{r}{}
\end{tabular}

Berdasarkan Tabel 8, dapat diketahui bahwa perolehan n-gain score sekitar 0,58 - 0,81 berkategori sedang hingga tinggi. Sebanyak 8 peserta didik mengalami peningkatan kategori tinggi serta 4 peserta didik mengalami perbaikan kategori sedang, dengan persentase 66,67\% tinggi dan 33,33\% sedang. Rata - rata nilai pretest peserta didik sebesar 41,17 sedangkan rata - rata posttest sebesar 83,33, dengan rata - rata $N$-Gain score sebesar 0,71 pada kategori tinggi. Hasil rata - rata persentase tiap indikator berpikir kritis mulai dari elementary clarification, basic support, inference, dan advanced clarification berturut - turut sebesar 85,95\%; 81,25\%; 79,17\%; dan 87,5\%. Pada indikator elementary clarification beberapa peserta didik juga masih kurang mampu menjelaskan sifat atau karakteristrik dari larutan elektrolit kuat dan lemah dengan penyajian gambar pada soal. Pada indikator inference sebagian peserta didik masih kurang mampu untuk membuat suatu kesimpulan dari hasil percobaan yang disajikan dalam soal. Beberapa peserta didik juga kurang mampu dalam menjelaskan penyebab tidak semua jenis air mampu menghantarkan arus listrik. Keterampilan berpikir kritis dikatakan berhasil dilatihkan apabila diperoleh nilaipaling rendah di kategori baik pada pembelajaran, sedangkan pada penelitian ini memperoleh rata - rata pada kategori sangat baik. Berdasarkan hasil yang diperoleh, menunjukkan bahwa LKPD berbasis POE yang dikembangkan efektif untuk mengajarkan keahlian berpikir kritis peserta didik pada materi daya hantar listrik larutan. Selanjutnya analisis mengenai ketuntasan hasil belajar peserta didik menunjukkan bahwa dari hasil pretest 91,67\% peserta didik dinyatakan belum tuntas dengan rata - rata nilai yang diperoleh sebesar 44,17; sedangkan dari hasil posttest 100\% peserta didik 
dikatakan tuntas dengan rata-rata nilai posttest yang didapat 83,33. Hal ini berarti seluruh peserta didik mendapatkan nilai akhir $\geq 75$ (KKM) dan ketuntasan klasikal yang diperoleh sebesar $100 \%$. Hal ini menunjukkan bahwa LKPD berbasis POE dapat dinyatakan efektif. Grafik mengenai hasil ketuntasan hasil belajar peserta didik dapat dilihat pada Gambar 3.

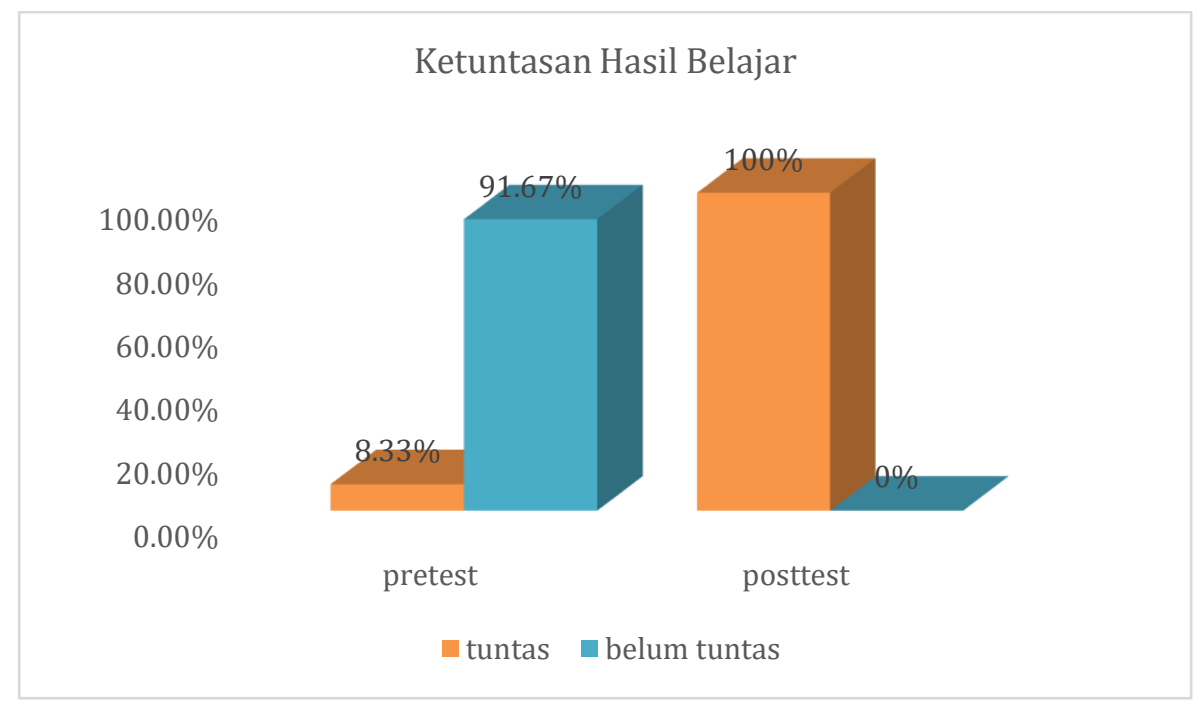

Gambar 3. Ketuntasan Hasil Belajar Peserta Didik

\section{Pembahasan}

Berdasarkan hasil analisis penelitian dapat diketahui bahwa media LKPD berbasis model POE yang dikembangkan berada pada kriteria sangat valid, hal ini dapat dilihat dari tiap-tiap komponen LKPD yang dirancang sedemikian rupa sehingga dapat memenuhi kebutuhan dan mengatasi permasalahan belajar kimia siswa. Hasil validitas menyatakan bahwa setiap aspek menghasilkan skor validitas yang berbeda-beda. Validitas isi terdiri dari 3 aspek validitas, yaitu sesuai atau tidaknya LKPD dengan materi, sesuai atau tidaknya LKPD dengan model pembelajaran POE, dan sesuai atau tidaknya LKPD dengan domain keterampilan berpikir kritis yang mencakup basic support, elementary clarification, inference, dan advanced clarification. Pertama kesesuaian LKPD dengan materi yang menunjukkan materi telahselaras dengan kurikulum 2013 yang sedang dipakai, sesuai atau tidaknya indikator dengan kompetensi dasar, akurat atau tidaknya fakta, materi telah sesuai dengan tujuan pembelajaran, dan sesuai atau tidaknya pertanyaan dengan indikator. Kesesuain materi yang disajikan dengan indikator dan tujuan pembelajaran merupakan salah satu komponen penting dalam penyusunan LKPD, hal ini dikarenakan indicator dan tujuan pembelajaran akan mengarahkan proses pembelajaran sehingga mampu memenuhi tuntutan pelaksanaan pendidikan (Astuti et al., 2018; Dewi \& Azizah, 2019).

Selanjutnya pada komponen penyajian LKPD berbasis model POE memperoleh hasil sangat valid, hal ini dikarenakan LKPD disajikan dengan lima aspek yaitu penyajian gambaran sesuai dengan materi, variasi tampilan menarik, tersedia tempat untuk menuliskan jawaban, kesesuaian dengan konsep yang runtut dan seimbang, serta kelengkapan penyajian komponen pada LKPD. Penyajian LKPD yang menarik dan sesui dengan karakteristik siswa tentunya akan menarik perhatian siswa untuk membaca dan memahami LKPD yang disajikan (Muthoharoh et al., 2017; Rachman et al., 2017). Gambar-gambar yang disajikan juga telah disesuaikan dengan materi yang ada sehingga mampu meningkatkan pemahaman siswa (Pranowo et al., 2021). Selain disajikan dengan gambar serta penyajian yang menarik LKPD berbasis model POE juga disajikan dengan bahasa yang mudah dipahami oleh siswa. Terdapat 4 aspek sesuai atau tidaknya LKPD dengan kebahasaan antara lain bahasa yang digunakan baik dan benar, struktur kalimat yang jelas, bahasa yang komunikatif, serta penggunaan istilah dengan benar serta tidak sulit dipahami. Penggunaan bahasa yang tepat tentunya akan memudahkan siswa untuk memahami maksud dari LKPD yang disajikan, sehingga tujuan pembelajaran lebih cepat tercapai (Satura et al., 2021). Uji valitas mengenai kegragifikan juga menunjukkan hasil bahwa LKPD berbasis model POE sangat valid untuk dikembangkan. Terdapat 4 aspek kesesuaian LKPD kriteria kegrafikan yaitu penggunaan font memudahkan dalam penggunaan LKPD, kesesuaian background dengan warna tulisan, tata letak teks, gambar, tabel serasi, serta cover mempresentasikan isi LKPD. Komponen-komponen kegrafikan yang baik akan membuat siswa lebih nyaman dan mudah dalam mengerjakan LKPD. Ukuran font yang tidak terlalu besar atau kecil dengan warna yang sesuai akan mudah untuk dibaca dan dipahami, selain itu penggunaan 
background yang sesuai akan memberikan kesan nyaman pada saat mengerjakan LKPD yang diberikan (Khoirunisa et al., 2019).

Selain telah teruji validatasnya LKPD yang dikembangkan juga dapat meningkatkan aktifitas belajar serta kemampuan berpikir kritis siswa. Peningkatan aktifitas belajar dan kemampuan berpikir kritis tidak terlepas dari penggunaan model POE. Seperti yang sudah dijelaskan sebelumnya bahwa model POE merupakan model pembelajaran yang memungkinkan peserta didik untuk dapat mengeksplorasi gagasan awal, mengidentifikasi konsep yang belum dipahami, mendiskusikan dengan baik, serta menigkatkan rasa ingin tahu peserta didik atas permasalahan yang ada. Penggunaan LKPD berbasis POE melibatkan berbagai aspek, tidak hanya pada pengetahuan saja namun sikap dan keterampilan berpikir kritis juga sehingga adanya peningkatan kompetensi peserta didik (Istiqomah et al., 2019). LKPD yang dikembangkan dengan model POE mengajak peserta didik untuk belajar secara sistematis untuk menemukan suatu upaya pemecahan masalah. Hasil yang diperoleh pada penelitian ini sejalan dengan hasil penelitian sebelumnya yang juga menunjukkan bahwa model pembelajaran POE mampu meningkatkan kemampuan berpikir kritis peserta didik (Alfiyanti et al., 2020). Penelitian lainnya juga menyebutkan bahwa strategi POE dapat digunakan saat melakukan pelatihan keterampilan berpikir kritis hal ini dapat dilihat melalui perolehan persentase nilai gains score sebesar $6 \%$ kategori rendah, $26 \%$ kategori sedang dan 68\% kategori tinggi (Amaliyah \& Harun, 2019). Penelitian selanjutnya menyebutkan bahwa media LKPD berbasis PBL valid dikembangkan dan dibelajarkan dalam pembelajaran kimia, karena dapat bersifat praktis, efektif, dan mampu meningkatkan kemampuan berpikir kritis siswa (Astuti et al., 2018). Hasil penelitian tersebut menunjukkan bahwa media LKPD berbasis model POE dapat membantu guru untuk meningkatkan pemahaman peserta didik pada materi kimia serta membantu proses belajar peserta didik.

\section{SIMPULAN DAN SARAN}

Berdasarkan hasil analisis penelitian dan pembahasan dapat disimpulkan bahwa media LKPD berbasis model POE sangat valid untuk dikembangkan dan dibelajarkan kepada siswa.Hal ini dikarenakan LKPD berbasis POE yang dikembangkan telah memenuhi kelayakan karena telah memenuhi kriteria valid, praktis, dan efektif sehingga layak digunakan untuk melatihkan keterampilan berpikir kritis peserta didik pada materi daya hantar listrik larutan.

\section{DAFTAR RUJUKAN}

Ain, Q., \& Mitarlis. (2020). Pengembangan LKPD Berorientasi Inkuiri Terbimbing untuk Meningkatkan Literasi Sains pada Materi Faktor - Faktor yang Mempengaruhi Laju Reaksi. Unesa Journal of Chemical Education, 9(3), 397-406. https://doi.org/10.26740/ujced.v9n3.p397-406.

Alfiyanti, I. F., Budi, J., \& Wasis. (2020). The Effectiveness of Predict Observe Explain (POE) Model with phET to Improve Critical Thinking Skills of Senior High School Students. Studies in Learning and Teaching, 1(2), 76-85. https://doi.org/10.46627/silet.

Amaliyah, M., \& Harun, N. (2019). Melatihkan Keterampilan Berpikir Kritis Peserta Didik Melalui Strategi Predict Observe Explain (POE) pada Materi Kesetimbangan Kimia Kelas XI SMAN 11 Surabaya. Unesa Journal of Chemical Education Education, 8(3), 313-319. https://doi.org/10.26740/ujced.v8n3.p\%25p.

Anggraini, S. A. P., Lesmono, A. D., \& Handono, S. (2017). Pengembangan Lembar Kerja Siswa (LKS) Fisika Berbasis POE Materi Gerak Harmonis Sederhana di MAN. Seminar Nasional Pendidikan Fisika 2017, 2(1), 1-7. https://jurnal.unej.ac.id/index.php/fkipepro/article/view/6375.

Astuti, S., Danial, M., \& Anwar, M. (2018). Pengembangan Lkpd Berbasis Pbl (Problem Based Learning) Untuk Meningkatkan Keterampilan Berpikir Kritis Peserta Didik Pada Materi Kesetimbangan Kimia. Chemistry Education Review (CER), 1(2), 90. https://doi.org/10.26858/cer.v0i1.5614.

Azizah, M., Sulianto, J., \& Cintang, N. (2018). Analisis Keterampilan Dasar Berpikir Kritis Siswa Sekolah Dasar pada Pembelajaran Matematika Kurikulum 2013. Jurnal Penelitian Pendidikan, 35(1), 6170. https://doi.org/10.15294/jpp.v35i1.13529.

Basir, S. A., Muharram, \& Danial, M. (2018). Pengembangan Perangkat Pembelajaran Dengan Menggunakan Strategi POE Pada Materi Pokok Asam Basa Untuk Meningkatkan Hasil Belajar $\begin{array}{lllll}\text { Peserta Didik.Chemistry Education Review } & \text { (CER), } 115 .\end{array}$ https://doi.org/10.26858/cer.v0i1.5615.

Chairani, P. R., \& Muchlis. (2019). Penerapan Model Pembelajaran Berbasis Masalah untuk Melatihkan Kemampuan Berpikir Kritis Peserta Didik pada Materi Larutan Penyangga Kelas XI di MAN 1 Sidoarjo. Unesa Journal of Chemical Education, 8(1), 16-21. 
https://jurnalmahasiswa.unesa.ac.id/index.php/journal-of-chemical-

education/article/view/27049.

Dewi, R., \& Azizah, U. (2019). Pengembangan Lembar Kerja Peserta Didik (LKPD) Berorientasi Problem Solving untuk Melatihkan Keterampilan Berpikir Kritis Peserta Didik Kelas XI pada Materi Kesetimbangan Kimia. Jurnal of Chemical Education, 8(3). https://doi.org/10.26740/ujced.v8n3.p\%25p.

Farib, P. M., Ikhsan, M., \& Subianto, M. (2019). Proses berpikir kritis matematis siswa sekolah menengah pertama melalui discovery learning. Jurnal Riset Pendidikan Matematika, 6(1), 99-117. https://doi.org/10.21831/jrpm.v6i1.21396.

Hamidah, N., Sri, H., \& Sri, W. (2018). Efektivitas Lembar Kerja Peserta Didik Berbasis Inkuiri Terbimbing untuk Meningkatkan Hasil Belajar Siswa. Jurnal Inovasi Pendidikan Kimia, 12(2), 2212-2223. https://journal.unnes.ac.id/nju/index.php/JIPK/article/view/7460.

Islamiyah, B. M. W., Al Idrus, S. W., \& Anwar, Y. A. S. (2019). Pengaruh Model Pembelajaran Predict, Observe and Explain (POE) Terhadap Kemampuan Berpikir Kritis Siswa. Chemistry Education Practice, 2(2), 14. https://doi.org/10.29303/cep.v2i2.1294.

Ismawati, R. (2017). Strategi React Dalam Pembelajaran Kimia SMA. Indonesian Journal of Science and Education, 1(1). https://doi.org/10.31002/ijose.v1i1.413.

Istiqomah, N., Bambang, S., \& Lailatul, N. (2019). Analisis Hasil Belajar Siswa Melalui Pembelajaran Menggunakan LKS Berbasis POE (Predict, Observe, Explain) Berbantu PHeT Simulation. Jurnal Pembelajaran Fisika FKIP Universitas Jember, 8(4), 248-255. https://doi.org/10.19184/jpf.v8i4.15233.

Khoirunisa, A., Haryati, S., \& Rery, R. (2019). Pengembangan Lembar Kegiatan Peserta Didik (LKPD) Berbasis Preview, Question, Read, Reflect, Recite, Review (Pq4r) Pada Pokok Bahasan Kesetimbangan Ion Dan pH Larutan Garam. J-PEK (Jurnal Pembelajaran Kimia), 4(2), 72-80. https://doi.org/10.17977/um026v4i22019p072.

Maemunah. (2020). Kebijakan Pendidikan Pada Era Revolusi Industri 4.0. Prosiding Seminar Nasional Lembaga Penelitian Dan Pendidikan (LPP) Mandala. https://doi.org/10.1234/.v0i0.423.

Makhrus, M., Harjono, A., Syukur, A. B., \& Muntari, S. (2018). Identifikasi kesiapan LKPD guru terhadap keterampilan abad 21 pada pembelajaran IPA SMP. Jurnal Ilmiah Profei Pendidikan, 3(2), 124128. https://doi.org/10.29303/jipp.v3i2.20.

Muna, I. A. (2017). Model Pembelajaran POE (Predict, Observe, Explain) dalam Meningkatkan Pemahaman Konsep dan Keterampilan Proses IPA. Jurnal Studi Agama, 5(1), 17-26. http://ejournal.kopertais4.or.id/mataraman/index.php/washatiya/article/view/3028.

Muthoharoh, M., Kirna, I. M., \& Indrawati, G. ayu. (2017). Penerapan Lembar Kerja Peserta Didik (LKPD) Berbasis Multimedia untuk Meningkatkan Motivasi dan Hasil Belajar Kimia. Jurnal Pendidikan Kimia Indonesia, 1(1), 13. https://doi.org/10.23887/jpk.v1i1.12805.

Novita, D. (2018). Keterampilan Berpikir Kritis Siswa Pada Materi Laju Reaksi Di Kelas XI MIA SMA Negeri 1 Manyar. J-PEK Jurnal Pembelajaran Kimia), 3(2), 19-30. https://doi.org/10.17977/um026v3i22018p019.

Nuraini, N., Fitriani, F., \& Fadhilah, R. (2018). Hubungan Antara Aktivitas Belajar Siswa Dan Hasil Belajar Pada Mata Pelajaran Kimia Kelas X SMA Negeri 5 Pontianak.AR-RAZI Jurnal Ilmiah, 6(1). https://doi.org/10.29406/arz.v6i1.939.

Nurazizah, S., Sinaga, P., \& Jauhari, A. (2017). Profil Kemampuan Kognitif dan Keterampilan Berpikir Kritis Siswa SMA pada Materi Usaha dan Energi. Jurnal Penelitian \& Pengembangan Pendidikan Fisika, 3(2), 197-202. https://doi.org/10.21009/1.03211.

Pranowo, M. I., Linda, R., \& Haryati, S. (2021). Pengembangan LKPD Kimia Berbasis Science, Environment, Technology, and Society (SETS) Materi Laju Reaksi. JRPK: Jurnal Riset Pendidikan Kimia, 11(1), 41-45. https://doi.org/10.21009/JRPK.111.07.

Putri, D. S., Dewa, P. N., \& Ismu, W. (2018). Pengembangan Lembar Kerja Peserta Didik Berbasis Predict Observe Explain pada Mata Pelajaran Fisika SMP. Jurnal Pembelajaran Fisika, 6(2), 161-174. http://jurnal.fkip.unila.ac.id/index.php/JPF/article/view/16247/0.

Rachman, F., Ahsanunnisa, R., \& Nawawi, E. (2017). Pengembangan LKPD Berbasis Berpikir Kritis Materi Kelarutan dan Hasil Kali Kelarutan pada Mata Pelajaran Kimia di SMA. ALKIMIA : Jurnal Ilmu Kimia Dan Terapan, 1(1), 16-25. https://doi.org/10.19109/alkimia.v1i1.1326.

Redhana, I. W. (2019). Mengembangkan Keterampilan Abad Ke-21 Dalam Pembelajaran Kimia. Jurnal Inovasi Pendidikan Kimia, 13(1). https://journal.unnes.ac.id/nju/index.php/JIPK/article/view/17824/8934.

Riduwan. (2015). Skala Pengukuran Variabel-Variabel Penelitian. Alfabeta.

Rizalini, R., \& Sofyan, H. (2018). Pengembangan lembar kerja peserta didik kimia berbasis inkuiri 
terbimbing untuk kelas Xi IPA SMA/MA. Jurnal Inovasi Teknologi Pendidikan, 5(2), 103-114. https://doi.org/10.21831/jitp.v5i2.14445.

Satura, Y. T., Abdullah, A., \& Rery, R. U. (2021). Pengembangan LKPD Aplikatif Integratif Berbasis Inquiri Terbimbing Pada Materi Kesetimbangan Kimia. Jurnal Pijar Mipa, 16(1), 64. https://doi.org/10.29303/jpm.v16i1.1647.

Sugiyarti, L., Alrahmat, A., \& Mursalin. (2018). Pembelajaran Abad 21 di SD. Prosiding Seminar Dan Diskusi Nasional Pendidikan Dasar, 439-444. http://journal.unj.ac.id/unj/index.php/psdpd/article/view/10184.

Sugiyono. (2013). Metode Penelitian Pendidikan Pendekatan Kuantitatif, Kualitatif, dan R\&D. Alfabeta.

Suhaesa, A. A. as, Andayani, Y., Muti'ah, M., \& Anwar, Y. A. S. (2019). Pengaruh Model Pembelajaran Predict-Observe-Explain (POE)Terhadap Pemahaman Konsep Siswa Materi Kesetimbangan Kelarutan Kelas XI MIA SMAN 2 Labuapi Tahun Ajaran 2017/2018. Chemistry Education Practice, 1(2), 27. https://doi.org/10.29303/cep.v1i2.956.

Sumartini, T. S. (2017). Meningkatan Kemampuan Komunikasi Matematis Siswa Melalui Model Pembelajaran Predict Observe Explanation. Jes-Mat (Jurnal Edukasi Dan Sains Matematika), 3(2), 167. https://doi.org/10.25134/jes-mat.v3i2.689.

Susilowati, S., Sajidan, S., \& Ramli, M. (2018). The Effectiveness of Inquiry-Based Module to Empower the Studentsr Critical Thinking Skills. Proceedings of the 1st Annual International Conference on Mathematics, Science, and Education (ICoMSE 2017), 1(1), 141-148. https: //doi.org/10.2991/icomse-17.2018.25.

Syamsuar, \& Reflianto. (2018). Pendidikan Dan Tantangan Pembelajaran Berbasis Teknologi Informasi Di Era Revolusi Industri 4.0. E-Tech: Jurnal Ilmiah Teknologi Pendidikan, 6(2). https://doi.org/10.24036/et.v2i2.101343. 